\title{
NAZEWNICTWO EUCHARYSTYCZNE U ŚW. AUGUSTYNA Aspekt filologiczny
}

S $t$ a b a d a ń. Wypowiedzi św. Augustyna na temat eucharystii były przedmiotem Już kilku opracowan. Ze starszych autorów usiłujących przedstawić augustyńską naukę o eucharyst11, należy wymienić K. Adama ${ }^{1}$, G. Lecordiera ${ }^{2}$, a przede wszystlsim P. W. Roetzera ${ }^{3}$, który w opublikowanej w $1930 \mathrm{r}$. dysertacj1 doktorskiej z zakresu historii liturgii potraktował pisma św. Augustyna jako swiadectwa o eucharyst1i, rozpatrywanej $w$ aspekcie ofiary eucharystycznej ${ }^{4}$ i sakramentu ołtarza ${ }^{5}$. Wymieniz tam takze przyirładowo kilkanaście augustyńsicich nazw na jej określenie. Po II wojnie światowej P. Th. Camelot ${ }^{6}$, podjąwszy ponownie ten temat, podkreślał problem realizmu i symbolizmu w eucharystycznej doktrynie Biskupa IIippony, a A. F. Xrager ${ }^{7}$ ofiarniczy charakter tego sakrarentu. Zwiezze informacje wprowadzające do dalszych opracowán tego zagadnienia z wyliczeniem odpowiednich miejsc źródłowych podał później I. Bieda ${ }^{8}$, a G. C. Ferlisi zwrócił uwage na augustyŕskie refleksje eucharystyczno w aspekcie duchowośc1.

Z $r$ ó d $¥$ a. Wśród pism św. Augustyna nie ma osobnego

1 K. Adam, Die Eucharistielehre des hl. Augustin, Paderborn 1908.

2 G. Lecordier, La doctrine de l'eucharistie chez saint Augustin, Paris 1930.

3 P. Wunibald lioetzer, Des heiligen Augustinus Schriften als liturgiegeschichtiliche Quelle, Mllnchen 1930.

4 Tamże, 95-135.

5 Tamże, 173-179.

6 P. Th. Camelot, Réalisme et symbolisme dans la doctrine eucharistique de saint Augustin, "IRevuc de sciences philosophiques et théoloriques" 31/1947/ 394-410.

7 A. F. Krtger, Synthesis of sacrifice according to saint Augustine. A study of the sacratilentality of sacrifice, Mundelein 1950.

8 I. Bieda, Euchryistis, Sirp $489-490$ 
dzieła poświęconego eucharystii, ale jest ona przedmiotem wielu jego krótszych lub dłuższych wypowiedzi, głównie jako komentarzy do tekstów biblijnych. Tylko w niektórych jego kazaniach/sermones/, skierowanych głównie do dzieci /ad infantes/, stanowi ona wyłazczny temat, jak mowa 227 przeznaczona na Niedziele Wielkanocną ${ }^{10}$ i 272 na Niedzielę Zesłania Ducha Swiętego ${ }^{11}$. Inne natomiast drobniejsze wypowiedzi o eucharystii moźna spotkać przede wszystikim w pozostałych jego mowach, często takze w "Homiliach na biwangelie św. Jana" 1 w "Objaśnieniach Psalmów", rzadziej wi "Wyznaniach", w traktacie "O Trójcy" i "O Państwie Bożyn" oraz w niektórych listach ${ }^{12}$.



we d $\mathbf{u} \mathrm{g} R \circ \mathrm{e} t \mathrm{t}$ e $\mathrm{r}$ a. P. Wunibald Roetzer stwierdza ${ }^{13}$, że Augustyn wypowiada się niezliczonaz ilość razy na temat ofiary eucharystycznej, nazywając ją najczęściej sacrificium ${ }^{14}$, a rzalziej określeniem ${ }^{15}$ : fidelium sacramentum, redemptionis sacramenta, ministcrium dominici corporis, sacra hysteria, oblatio, verissimum et singulare sacrificium, summum verumque sacrificium, sacrificium quod nunc a Christianis offertur Deo toto orbe terrarum, universale sacrificium, sacrificium Chrisiianorum, sacramentum altaris fidelibus notum, magnum sacrainentum, laudis sacrificium, sacriflclum corporis Christi ${ }^{16}$. Poniewaz wyinienione wyżej określenia eucinarystil nie wyczerpuja całego jej bogactwa, wypada uzupełnić ich liczbe i zaproponować ich polskie odpowiedniki z uwzględnieniem najbliższego kontekstu w przekzadzie własnym autora.

$$
\text { P r o p o z y c } j e \quad b \text { a d a w c z e. Terminy eucha- }
$$
rystyczne, jakie znajduja sie w pismach Biskupa Hippony moźna

9 G. C. Ferlisi, Il pane eucaristico, quiete del nostro cammino. Riplessioni agostintane sull'Eucaristia, Roma 1980.

10 Sermo 227 /De sacramentis in die Paschae/, PL 38, 1099-1101.

11 Serno 272 /De sacramento in die Pentecostes/, PL 38, 1246-1248.

12 Por. Epistolae: 9, 36, 54, 98, 140, 149, 158, 186, 217.

13 Roetzer, dz.cyt., 95 .

14 Roetzer odsyła czytelnika nrzy tya wyrazie do Index in omnia opera sancti Aurustini, PL 46, 579-581.

15 loetzer/dz.cyt., 95-97/ podaje ich lokalizacje w pismach augus tyrisich.

16 Wyliczenie wylienionyci określeń u koetzera jest tylko przyk tad owe. 
zestawić w czterech grupach. Trzy pierwsze zawieraja takie kluczowe wyrazy, jak: eucharistia, sacramentum i sacrificium, czwarta zaś pozostałe teriiny $i$ wyrazenia. Zestawienia te moga posłuzyé do dalszycil problemowych opracowań, przekraczających rany tego artyicułu. Z konieczności więc należało poprzestać na zwięzłych tylko wyjaśnieniach poprzedzających przytaczane teksty, które mogaz ułatwić nalésyte zrozumienie zawartości treściowej poszczególnych terminów eucharystycznych, zwłaszcza w tych wypadkach, kiedy łacińskie terminy nie dadza się przetłumaczyć na język polski jednoznacznie/np. communio czy communicatio/, bez uwzględnienia ich najblizszego konteistu.

Niniejsze opracowanie jest próbą uwzględnienia przede wszystikim aspektu filologicznego w badaniach nad nauką o eucharystil u św. Augustyna. Autor tego opracowania nle rości sobie pretensji do wyczerpujacego ujęcia zaproponowanego mu tematu.

\section{EUCHAR ISTIA}

Eucharystia oznacza dziękczyniente, zwłaszcza ofiare dziękczynną. Laciński wyraz "eucharistia" jest odpowiednikiem greckiego terminu $\varepsilon u ̉ x \alpha \rho \iota \sigma \tau \iota \alpha$ lub $\varepsilon \cup ̉ x \alpha \rho \iota \sigma \tau \varepsilon l \alpha$ używanego w greckich tekstach literatury chrześcijańskiej na oznaczeniegłómnie "dzlękczynienia", zwłaszcza "biblijnej ofiary dziękczynnej"17. Sw. Augustyn zaś posługuje się tym wyrazem w róznych kontekstach.

1. "Eucharistia et corporis et sanguinis Domini" "Eucharystia zarówno Ciała, jak i Krwi Paískiej"

Gdy Biskup Hippony wspomina o ofierze dziękczynnej, złożonej przez Melchizedeka po zwycięstwie Abrahama nad wrogami, stwieraza, że jest ona obrazem i zapowiedzią eucharysti1: "Informację o eucharystii zarówno Ciała Jak 1 Krwi Pańskiej po raz pierwwszy podat/Melchizedek/ Abrahamowi, ojcu wierzacych pontekąd, aby w ojcu został przedstawiony jej obraz" 18.

17 Por. G. W. II. Lailpe, A Patristic Greek Lexicon, oxford 1972, 579-580.

18 Qaestiones ex utroque Testanento mixtim. De Melchisedech 109, PL 35, 2328: "I am Melchisedech /.../ Abrahae primum, quasi 


\section{2. "Prima eucharistia" \\ "Pierwsza eucharystia"}

Taka nazwa określa św. Aujustyn eucharystię sprawowana "po raz pierwszy" osobiście przez Chrvstusa 1 w łasnorecznie podaną przez Niego zarówno zdrajcy, jak 1 pozostałym apostołom: "Chrystus /.../ z tak wielkqz cierpliwościaz zniósł swojego zdrajcę, że podał mu pierwsza eucharystię sprawowaná własnymi rękami 1 zleconaz mu do sprawowania swoimi ustami, tak jak 1 pozostałym apostołom"10.

\section{3. "Acceptionem Eucharistiae dominicam cenam vocans"} "Przyjecie eucharystil otrzymuje nazwe uczty Pańskiej"

"Takie waśnie przyjęcie eucharystii nazywa apostoł", jak mówi św. Augustyn o św. Pawle, "ucztą Pariską"20.

4. "Da nobis hodie Eucharistian tuam, quotidianum cibum" "Daj nam dzisiaj, Twoją eucharystie, pokarm na codzieńl"

Biskup Hippony nazywa elcharystie "pokarmen na codzien", - Jaki prosimy Boga 0jca w Modlitwie Pańskiej słowani: "'chleba naszego powszedniego daj nam dizisiaj', daj nam dzisiaj Twoją eucharystię, pokarm na codzień"21.

5. "Eucharistia panis noster quotidianus est l" "iucharystia jest naszym chlebem na codzieńl"

Dlatogo św. Augustyn zaleca wiernya codzienne przyjmowanie eucharysti1: "Dlatego codziennie, dlatego dziś, tj. w tej

patri Pideliun, tradidit bucharistiam et corporis et sanguinis Domini, ui praefiguraretur in patre".

19 Enarrationes in Psalmum 10,6, PL 36, 135: "Christus quod vobis fecit, qui traditorem suum tanta patientia pertulit, ut e1 primam Eucharistiam confectam manibus suis et ore suo commendatan sicut ceteris apostolis traderet?"

20 Epistola 54, 7, PL 33, 203: "Apostolus nanque alibi dicit: 'Convenientibus erto vobis in unum, non est lominicam cenam manducare' /Cor 11, 20/, hanc ipsain acceptionem bucharistiae domintcarn cearam vocans".

21 Ser!no 58, 5, PL 38, 395: "'paner nostrum quotidjanum da nob1s hodie', Lucharistiam tuan, quotidianum cibum". 
chw11i"22.

6. "Eucharistian quotidie ad cibum salutis accipimus" "Codziennie przyjmujemy eucharystie na pokarm dla naszego zbawienia"23.

Przyjmowanie eucharystii określa Pasterz Hippony czasownikiem "accipere"24, Innym razem czasownikiem "sumere" 25 albo rzeczownikiem "acceptio"26.

\section{7. "Sacramentum Eucharistiae" "Sakrament eucharystii"}

Wyraz eucharistia łączy się u św. Augustyna także z wyrazen sacramentum w powyższyin określeniu: "sakrament eucharysti1"27.

\section{SACRAMENYUM}

Eucharystia jest sakranenteil, czyli świętyn znakiem ${ }^{28}$. W pismach św. Augustyna wielokrotnie występuje nazwa sacramentum stosowana na określenie eucharystil sarjodzielnte 1 w połączeniu z innymi wyrazami.

Przykładem samodzielnego uzycia tego wyrazu może być wypowiedź podana przy wyjaśnianiu uczniom przez Chrystusa tajemnicy eucharysti1: "Wskazałen wam wewnym stopniu na sakrament. 0żywi

22 Sermo 57, 7, PL 38, 389: "Eucharistia panis noster quotidianus est: sed sic accipiamus illum, ut non solum ventre, sed et mente reficiamur $/ \ldots . /$ Ideo quotidie, ideo hodie, id est, hoc tempore".

23 Contra duas epistulas Pelagianorum 4, 25, PL 44, 627: "Eucharistiam quotidie ad cibum salutis accipimus"; por. De bono perseverantiae 7, PL 45, 998: "Eucharistiam quotidie ad clbum salutis accipimus".

24 Por. Contra duas epistulas Pelagianorum 4, 25, PL 44, 627: "accipimus", De bono perseverantiae 7, PL 45, 998: "accipimus"; Sermo 57, 7, PL 38, 389: "Eucharistiam accepturi sumus"; Epistola 54, 4, FL 33, 201: "quotidie accipiendam Eucharist1ain".

25 Por. Epistola 54, 7, PL 33, 203: "sumerent Eucharistiam". 26 Por. Epistola 54, 7, PL 33, 203: "acceptionem Eucharistiae".

27 Enarrationes in P'salmum 103, 14, PL 37, 1348: "sacramentum Eucharistiae".

28 Etymologię sairramentu eucharystii jako "świętego znaku widzialnego ofiary niewidzialnej" podaje Augustyn we civitate Dei X 5, PL 41, 282 . 
was, jeśli zostanie zrozumiany duchowo. Chociaz jest rzeczą niezbędna sprawować go ze czcia w sposób widzialny, to jednak należy go pojmować w sposób niewidzialny" 29 . Wyraz sacramentum stosuje Biskup IIippony wielokrotnie równiés na określenie eucharystii, a gdy pisze o "modlitwach /.../, które wypowiadamy w czasie sprawowania sakramentów, zanim zacznie się błogosławić to, co jest na stole Pańskim"30, ma na myśli ofiarę eucharystycznaz.

A oto przeglazd połączeń wyrazu sacrarentum z innyini wyrazami, które odnoszą się do eucilarystił.

1. "Sacramentum Eucharistiae"

"Sakrament Eucharystit"

Tak więc eucharystię nazywa św. Augustyn sakramentem ${ }^{31}$.

2. "Sacramentum corporis Christi" "Sakrament Ciała Chrystusa"

Takie określenle eucharystii stosuje Biskup Hippony, k1edy chwali kartagińskich chrześcijan za to, że "sakrament Ciała Chrystusa /.../ nazywaj iz życieli", 1 to "bardzo trafnie"32. To

29 Enarrationes in Psalmum 98, 9, PL 37, 1265: " Sacramentum aliquod vobis commendavi; spiritualiter intellectum vivificabit vos. Etsi necesse est illud visibiliter celebrari, oportet tailen invisibiliter intelligi".

30 Epistola 149, 15, PL 33, 636: "precationes /.../, quas fac1mus in celebratione Sacranentorum, antequam illud quod est in Donini mensa incipiat benedici". Por. Sermo 272, PL 38, 1247: "ipsum: Apostolum identideil audiamus, qui cum de isto Sacramento loqueretur, ait /1 Cor 10, 17/"; Epistola 54, 7, PL 33, 203: "tradidit/sc. Christus/'Sacramentum"; De civ1tate Dei XXI 25, 2, PL 41, 741: "sacranentum"; tainze XXI 25, 4, PL 41, 741: "ostendit quid sit non sacranento tenus, sel re vera corpus Christi manducare, et eius sanguinem bibere: hoc est entm in Christo manere, ut in illo maneat et Christus". O "przyjmowaniu sakrainentu" zob. Epistola 54, 8, PL 33, 203: "Sacramentum accioiendum"; Serao 354, 2, PL 39, 1563 i in.

31 Enarraliones in Psalmum 103, 14, PL 37, 1348.

32 De peccatorum aleritis et reaissione I 34, PL 44, 128: "Sacramentuil corloris Christi /.../ vitan vocant". 
samo określenie eucharysti jako "sakramentu Ciała Chrystusa"33 łączy Augustyn z wyrazem "chrzest", gdy pisze o katolikach przyjmujących "sakrament chrztu 1 Ciała Chrystusa"34 albo "sakrament Chrystusowego chrztu 1 Jego Ciała" ${ }^{35}$. Nazwanie eucharystii jako "sakramentu Ciała Chrystusa" jest u IHippończyka takźe elementem wypowiedzi w tych miejscach jego pism, guzle jest mowa o przyjmowaniu tego sakramentu nie tylko przez wiernych, lecz także przez heretyków i schizmatyków: "sakrament tego Ciaza"36 lub w wyowiedzi: "Wielu wprawdzie przyjnuje sakrament tego Ciała, ale nie wszyscy, którzy przyjmują sakrakent, będą táże zamieszkiwać u Niegro miejsce obiecane Jego członkom"37 albo dalej w tym samym miejscu: "prawie wszyscy przeciez twier$\mathrm{dz}$ ¿̨, że Jego Ciało jest sakrainenteni" 38 .

\section{3. "Eius sanguinis sacra!ventum"} "Sakrament Jego Krwi"

Sw. Aưustyn mówi o "dobrze znanym wszystkim ocinrzczonym sakramencie Jego Krwi", tj. Krwi Chrystusa ${ }^{39}$, stwierdzajac także, że "wierzłcy pili Jego Krew w sakramencie"40.

4. "Sacranentum corporis et sanguinis Christi" "Sakrament Ciała 1 Krwi Chrystusa"

Można tu wyıienić trzy augustyńskie warianty tego sformułowania: "sakrament złączenia w jedno Ciała i Krwi Chrystusa",

33 De civitate Lei XXI 25, 3, PL 41, 742: "sacranentum corporis Christi"; ipistola 36, 28, PL 33, 149: "In sacramento corporis Christi".

34 Tainze, XXI 25, 2, PL 41, 741: "sacramentun Baptismatis et corporis Christi"。

35 Taize, XXI 20,PL 41,734: "Baptismatis Christi et eius corporis" sacramentum".

36 Tamże, XXI 25, 2, PL 41, 741: "cuius corioris sacramentum" /dwukrotnie!/.

37 Sermo 354, 2, PL 39, 1563: "Corporis autem eius sacramentum multi acciniunt, sed non omnes, qui accipiunt sacramentum hablturi sunt apud eurn etian locum promissum menbris eius".

38 Tarrize: "Pene culden sacranentum onnes corpus eius dicunt".

39 De civilate Dei XVI, 41, PL 41, 520: "eius sunguinis sacramentum baptizati sciunt".

40 Serino 87, 14, $\mathrm{PL} 38,583$ : "in Sacrancinto credentes sarguinem eius biberunt:" 
"sakramenty mojego Ciała i Krwi" I "sakrarent Jego Ciała 1 Krwi".

a/ "Sacramentum /.../ unitatis corporis et sanguinis christi" "Sakrament /.../ złączenia w jedno Ciała i Krwi Chrystusa"

To sformułowanie znajuuje się w następującym kontekście: "Sakrament tej rzeczywistości, tj. złuczenia w jedno Ciaza 1 Krwi Chrystusa, przygotowuje się na stole Pańskim tu i tam codziennie, gdzie indziej no przerwie kilku dni 1 przyjmuje siq ze stołu Pańskiego" 41 .

\section{b/ "Sacramenta corporis et sanguinis mei" "Sakramenty mojego Ciała i Krwi"}

To sformułowanie jest parafrazowanq wypowiedzia Chrystusa: "Sakramenty mojego Ciała i Krwi oddam obecnie tym, którzy się Go boj ą" 42 .

c/ "Sacramentum carnis et sanguinis eius" "Sakrainent Jego Ciała i Krwi"

To sformułowanie jest zawarte w retorycznym pytaniu augustyśskim: "Czy Judasz, niogodzivy sprzedawca i zurajca swego iistrza, trwal w Chrystusie, albo Chrystus w nim, chociaz z pozostałymu uczniami spozywał i pił po raz pierwszy wiaśnie sprawoviany Jego rękami sakrament Jego Ciała i Krwi?"43

\section{5. "Sacramentum altaris" "Sakrament ołtarza"}

Takiego terminu używa znów Augustyn w następujących sforinuł ow aniach:

41 In Joannis Evangelium 26, 15, PL 35, 1614: "Huius rei Sacramentum, id est, unitatis corporis et sanguinis Christi alicubi quotidie, alicubi certis intervallis dierum in dominica mensa praeparatur, et de mensa dominica sumitur".

42 Enarrationes in Psalmum 21, 26, PL 36, 170: "sacranenta corporis et sanguinis mei reddam coram timentibus eum".

43 Sermo 71, 17, PL 38, 453: "Sacranentum carnis et sanguinis eius". 
a/ "Sacramentum altaris fidelibus notum" "Sakrament ołtarza, jakl 1 znaja wierni"

"Taka jest ofiara chrześcijan: 'wielu jest zjednoczonych w jednym Ciele Chrystusa'. Tę też ofiarę Kościóz powtarza przez sakrament ołtarza, jalki znają wierni"44;

\section{b/ "Sacramentum altaris" \\ "Sakrament ołtarza"}

"Mamy przyjąc sakrament ołtarza"45;

c/ "Altaris sacramenta"
"Sakramenty ołtarza"

"Sakramenty ołtarza przyjmują razem dobrzy 1 źli"45 A;

d/ "Sacramentum altaris sacri"

"Sakrament świętego ołtarza"

"Ŝr. Augustyn mówi "o sakramencie świętego ołtarza, który dziś zobaczyli /ochrzczen1/, ale nic dotąd o nim nie słyszeli, dziśs więc należy się im kazanie na ten temat" ${ }^{46}$;

\section{e/ "Sacramenta altaris" "Salkrainenty ołtarza"}

"Dziś trzeba mówić dzleciom o sakramentach ołtarza"47.

6. "Sacramentum caelestis panis"
"Sakrament niebiańskiego chleba"

Ten termin pojawia sią przy informacji o praktyce kościelnej czasoriego odsuntęcia kogoś od przyjmowania "sairramentu. nieblańskiego chleba" z racjl stanu niegodności po popełnienlu grze-

44 Do civitate Dei X 6, PL 41, 284: "sacramento altaris fidelibus noto".

45 Sermo 59, 6, PL 38, 401: "Sacranentun altaris habemus accipere".

45A Serno 95, 7, PL 38, 584: "altaris Sacramenta simul accipiunt bon1 et mali".

46 Sermo 228, 3, PL 38, 1102: "de Sacramento altaris sacri, quod hodie viderunt/sc. baptizati/, nihil adhuc audierunt, hodie illis de hac ro sermo debetur".

47 Sermo 226, PL 38, 1099: "de Sacramentis altaris hodie in- 
chu śmiertelnego 48 .

7. "Sacramentum pietatis"

"Sakrament miłosierdzia"

Ta nazwa eucilarystii urieszczona jest na początku pięknej, mocno zretoryzowanej wypowiedzi:

$$
\begin{aligned}
& \text { "O sakramoncie miłosierdzia! } \\
& \text { o znáku jedności! } \\
& \text { o węźle miłości!" }
\end{aligned}
$$

\section{8. "Magnum sacramentun"}

"Wielisi sakrament"

Biskup IIippony nazywa eucharystie "wielkim sakramenten"50, "salsramentem wielkiej rzeczywistości"51, "wielkimi, i to bardzo wielkimi sakramentari" Ciała i Krwi Chrystusa ${ }^{52}$.

9. "Magnum sacramentum in sacrificio Novi Testament1" "Wielki sakrament w ofierze Nowego Testamentu"

Tym "wielkim saikramentem" jest sakrament, przy sprawowaniu którego "dzięki składamy Panu Bogu naszemu" 53 .

10. "Tantum sacramentum"

"Tak wielki sakrament"

Sw. Augustyn wyjaśnia, że ze względu "na cześć dla tak wielkiego sakramentu Ciało Paŕskie powinno dostać się do ust

fantibus disputandum est.

48 Sermo 351, 7, PL 39, 1542: "per ecclesiasticam disciplinam a Sacramento caelestis panis/.../ separetur".

49 In Toannis Evangelium 26, 13, PL 35, 1613: "O Sacramentum pietatis, o signum unitatis, o vinculum caritatis!"

50 Sermo 232, 7, PL 38, 1111: "magnum sacramentum"。

51 Serro 272, PL 33, 1246: "magnae rei sacramentum".

52 Sermo 227, PL 38, 1101: "magna ergo sacramenta, et valde magna".

53 Epistola 140, 19, 48, PL 33, 558: "Hinc gratias agimus Domino Deo nostro, quod est magnum sacramentum in sacrificio Novi Testamenti". 
chrześcijanina wcześniej niż inne pokarmy"54, a "do tak wielkiego sakramentu może przystąpić ten, kto jest tego godzien" 55 , natomiast "po uczestnictwie : tak wielkim sakramencie dziekczynienie kończy wszystko" 56 .

\section{1. "Sacramentum tantae sanctitatis" \\ "Sakrament tak wielkiej świetośri"}

Ojciec Kościoła oświadcza, że "całkiew jawnie dopuszczający się cudzołóstwa i oznajmiający dalsze w nim trwanie powinni być powstrzymani, jak się wydaje, od sakramentu tak wielkiej świętości" ${ }^{5}$ ?

12. "Sacramentum mensae dominicae"

"Sakrament stołu Pasiskiego"

T'en eucharystyczny termin jest u Augustyna odpowiednikiem trzech łacinskich określeń:

a/ "Sacramentum mensae dominicae"

Sakrament ten jest przedmiotem wyjaśnienia ze strory św. Pawła a chrześcijanie nazywają go "życiem"59;

b/ "Mensae dominicae sacramentum" "Sakraient stołu pauskiego"

Jego tajemnicę wyjaśnia sam Biskup Hippony 60 .

54 Epistola 54, 8, PL 33, 203: "in honorem tanti Sacranenti".

55 Epistola 54, 4, ${ }^{2} \mathrm{~L}$ 33, 201: "Dixerit aliquis non quotidie accipiendam Eucharistiam: quaesieris quare. Quoniari, inquit, eligendi sunt dies quibus purius homo contentiusque vivit, quo ad tántum Sacramentum dignus accedat".

56 Epistola 149, 15, PL 33, 637: "participato tanto Sacrainento, gratiarum actio cuncta concludit".

57 De Pide et operibus 8, PL 40, 202: "apertissimi adulterii perpetratores et eius perseverantiae professores a jacranento tantae sanctitatis videantur arcenci".

58 Sermo 227, HL 30, 110: "Sic exposuit/sc. Apostolus/sacramentum mensae Dominicae".

59 De peccatorun meritis et reuissione I 34, PL 44, 128: "sacramentum mensae Dowinicae vitam vocant".

60 Sermo 227, PL 38, 1099: "Sermonew, quo exponerem mensae Dominicae Sacramentum". 
c/ "Sacramentum sanctae inensae suae"

"Sakraniat swojego świetego stołu"

Przystąpienie do "Sakrameiltu świętego stołu Chrystusa" przysługuje tylko ochrzczonym: "Posłuchajmy Pana /.../ mówiącego o sakramencie swojego świętego stołu, do którego przystępuje w sposób właściwy tylko ochrzczony" 61 .

13. "Sacramentum quotidianum"

"Sakrament spratowany codziennie"

Biskup IIfpony poucza, że Jezus Chrystus Jako człowiek stał się pośrednikiem między Bogiem i ludźmi, a przez to sam jaiso kapłan składajacy ofiare 1 sam jako ofiara, "chciał, aby spruwowany codziennie sakrament tej rzeczywistosci by ofiara Kościoła" 62 .

14. "Visibile sacranentum"

"Sakrament w widzialnej postaci"

Źródłem mocy tego sakramentu jest Chrystus, prawdziwy Bóg 1 prawdziwy Człowiek: "Chrystus skała/por. Lb 20, 11; 1 Kor 10, 1/ wnaku, Chrystus prawdziwy w Stowie i prawdziwy w Ciele /.../. Ale to odnosi sie do mocy sakramentu, a nie do sakramentu widzialnej postaci: odnosi sie do tego, kto spozywa wewnętrznie, a nie zewnętrznie, kto spożya w sercu; natomiast nie odnosi sie do tego, kto tylko dotyka zębawi", bo "czym Innym jest sakrament, a czym innym moc sakramentu. Jakije wielu przyjmuje z ołtarza 1 uniera, a przyjmujęc, dlaczego umiera? /.../. Fiedzcle więc, bracia, o tym, ze to chleb nieblański. Spozywajcie go duchowo. Przynoście do ołtarza niewinność. Choć są grzechy powszednie, niech nie będzie jednak śmiertelnych" 63 .

61 De peccatorum mertis et remissione I 26, PL 44, 123: "Dom1num audiamus /... dicentem de Sacranento sanctae mensae suae, quo nemo rite nisi baptizatus accedit".

62 De civitate De1 X 20, PL 41, 298: "mediator effectus est Dei et hominum homo Christus Iesus /.... Per hoc et sacerdos est, ipse offerens, ipse et oblatio. Cuius rei sacramentum quotidianum esse voluit Ecclesiae sacrificium".

63 In Ioannis Lvangelium 26, 12 i 11, PL 35, 1612 i 1611: "Petra Christus in signo, verus Christus in verbo et in carne /.../. Sed quod pertinet ad virtuter Sacramenti, non quod pertinet ad visibile Sacramentum: qui manducat intus, non foris; qui manducat in corde, non qui premit dente; $/ . . . /$ aliud est Sa- 


\section{5. "Dominicum sacramentum" "Sakrament Pański"}

Kto nlegodnie przyjmuje "sakrament Pariski", szkodzi nie sakramentowi, ale samemu sobie: "W ten sposób nikt, kto niegodnie przyjmuje sakrament Pański, nie powoduje tego, że sakrament staje sie zły, ponieważ on sam jest złyn"64.

\section{6. "Sacramentum P1delium"}

"Sakr ament wiernych"

Można przytoczyé takie augustyńskio wypowiedzi z tym terminem eucharystycznyin: "Wierni znaja sakrament wiernych"65; Chrystus "natomiast chce, aby przez Jego prośby rozumiano ofiare Jego Ciała, którą jest sakrament wiernych" 66 .

17. "Pretii nostri sacramentum"

"Sakrament naszego Odkupienta"

Tego terminu używa Augustyn w modlitwie za swoja zmarła matke, która z tym "sakramentem naszego Odkupienia" zwiazała sie wezłem wiary 1 przed ołtarzem za życia służyła Bogu codziennie bez przerwy 67 .

\section{8. "Redemptionis sacramenta" "Sakramenty Odkupienia"}

Podobny w treści do poprzedniego eucharystyczny termin znajduje sie w liscie biskupa Ewodiusza skierowanym do św. Augustyna $z$ takiz informacją: "trzeciego dnia odprawiliśmy sakra-

cramentum, aliud virtus Sacramenti. Quaw multi de altari accipiunt et moriuntur, et accipiendo moriuntur? /.../. Videte ergo, Pratres, panem caelestem spiritualiter manducate, innocentian ad altare apportate. Peccata etsi sunt quotidiana, vel non sint mortifera".

64 De baptismo contra Donatistas 5, 9, PL 43, 181: "sic indigne quisque sumens dowinicum Sacramentum, non efficit ut quia ipse malus est, malum sit".

65 Serno 131, 1, PL 38, 729: "Sacranentum tidelium agnoscunt rideles".

66 Lipistola 14U, 61, l'L 33, 563 : "Vota vero sua sacrificium vult intelligi corporis sui, quod est ridelium sicramentum".

67 Contessiones In 13, 36, il 32, 778: "pretii nostri sacramentum". 
menty Odkupienia" 68 .

19. "Saluberrimum sacramentum"

"Najskuteczniejszy sakrament zbarienia"

"Zbawienny w najwyższym stopniu sakrament"

Eucharystia nazwana tu jest "najskuteczniejszym sakramentem zbawienia"69.

20. "Invisibilis sacrificii sacramentum" "Sakrament ofiary niewidzialnej"

Wyraz "sacramentum" łączy sie u naszego Doktora Kościoła z wyrazem "sacrificiurn" w takim oto określeniu eucharystii: "Widoczna więc ofiara jest sakrailentem, to jest świętym znairiem ofiary niewidzialnej"70.

21. "Sacranentum memoriae"

"Sakrament sprawowany na pamiątkę".

Eucharystia jest paniątisa Męki Chrystusa. Zapowianały ja przed Jego przyjściem składane podobnie ofiary ze zwierzot ofiarnych: "Ciało i Krew tej ofiary zapowiadały przed przyjścien Chrystusa podobnie składane ofiary ze zwierząt ofiarnych /.../. Po wnieborstapieniu Chrystusa prawdziwe Ciało 1 Krew Chrystusa czci sie w paniątkowym obchodzie Męi przez sairrament sprawowany na pamiątkę" 71 .

22. "Celebratio sacramentorum"

"Sprawowanie sakramentóiv"

Ta nazwa oznacza u św. Augustyna ofiarę eucharystyczną: "jalso tzw. prośby rozumieny te wypowiedzi błagalne, jakte

68 Epistola 158, 2, PL 33, 694: "redemptionis Sacramenta tertio dic obtulimus".

69 Lpistola 54, 4, PL 33, 201: "saluberrimum Sacramentum".

70 De civitate De1 X 5, PL 41, 282: "Sacrificium ergo visibile invisibilis sacrificit sacranentum, id est sacrum signum, est".

71 Contra Faustum Manichacum 20, 21, PL 42, 385: "Iluius sacrif1cii caro et sanguis ante adventum Christi per victimas similitudinem promittebatur;/.../ post ascensum Christi per Sacramentun menoriae celebratur /.../ veritas in passione corporis et sangulnis Christi". 
wygłaszamy w czasie sprawowania sakramentów, zanim zacznie się błogosławić to, co jest na stole Pańskim, a waściwe modlitwy wypowiaciany wtedy, kiedy się to juz błogosławi, uświęca 1 rozdrabnia do rozdzielania; to całe błaganie kaźdy prawie Kościół kończy modlitwą Pańską"72.

\section{SACHIFICIUM}

Eucharystia jest ofiara, i Augustyn, kiedy mówi o ofierze eucharystycznej, posługuje się najczęściej terminem "sacrificium". Przypominając np. o obowiazzku wykonywania znaku krzyża nad darami ofiarnyai przed wymówieniem słów konsekracyjnyoh, pisał: "znak Chrystusa należy wykonywać nad ofiarą, która żywią się wierzący"73. Warto więc przyjrzes sie dokładniej kontekstovi wyrazu "sacrificium" - ofiara.

1. "Sacrificium secundum oridnem Melchisedec" "Ofiara składana na wzór ofiary złożonej przez Melchizedeka"

Eucharystia jest "ofiara składaną na wzór ofiary złożonej przez Melchizedeka"74. Melchizedek jest Pigurą Chrystusa: "Melchizedek /.../ to nasz Pan Jezus Chrystus. On chciaź być naszym zbawienlen w swoim Ciele i Krwi"75.

72 Epistola 149, 15, PL 33, 636: "ut precationes accipimus dictas, quas facimus in celebratione Sacramentorum, antequam illud quod est in Domini mensa incipiat benedici; orationes, cum benedicitur et sanctificatur, et ad distribuendum comminutur, quam totam petitionem fere omns Ecclesia domfnica oratione concludit".

73 In Ioann1s Evangclium 118, 5, PL 35, 1950: "Signum Christ1 /.../ adilibetur /.../ sacrificio, quo aluntur/sc. credentes"/.

74 Enarrationes in Psalmun 33, 5 i 6, PL 36, 303: "sacrificiun secundum ordinem Melchisedec".

75 Tamże, F, PL 36, 303: "lielchjsedec /.../ Dominus noster Iesus Christus. In coipore et singuine suo voluit esse salutem nostram". Por. Enarrationes in Psalmun 106, 13, PL 37, 1427: "sacrificium /.../; quaeris secuncium nrdineil Melchisedec;/.../ per totum orben celebratur in Ecclesia". 
2. "Tale sacrificium nunc offertur Deo toto orbe terrarum" "Taka ofiara teraz jest składana Bogu na całyn globie ziemskin"

Of 1 ara złożona przcz Melchizedeka jest obecnie wzorem ofiary skłalanej na całym świecic: "Wiedza ci, którzy czytaja, co przyntósi Helchizedén, kiedy błogosłarił Abrahamowi / .../, widzą taisiz oflare sistadana teraz Bogu na całym globle ziemskim"76.

3. "Sacrificiun cuod nunc a Christianis offertur Deo toto orbe terrarum"

"Opiara, jalsa teraz cinrześcijanie sisładaja Bogu na cały'n globie ziems'sim"

Ofiara złożona przez Melchizedeka jest obecnie wzorew eucharystycznej ofiary cirrześcijan: "wtedy to po raz pierwszy była widzialna oflara, jahį teraz chrześcijanie składaja Bogu na całym globie ziemsirim"77" "Pytasz o oftare/.../ składaną na wzór ofiary złożonej przez Ḿlchizedeka? / ‥ / Na całym globie zienskim jest składana w Kościele"78.

\section{4. "Sacrificium Novi Testamenti"} "Ofiara Nowego Testaruentu"

Ducilarystia jest "ofiarą Nowego Testamentu". Tak Augustyn określa eucharystię, kledy mówi o "krwawych ofiarach" sikładanych "z bojaźn przed Bogien przez ludzi Starego Testamentu". Te krwawe ofiary były składane "na znak przyszłej krwi, dijęki której zostaliśny odlupieni" $i$ "miały ustać"79 z nastaniem "opiary No-

76 Contra adversariua Legis et Prophetarum I 39, PL 42, 627: "Norunt qui legunt, quid protulerit Nelcisedec, quando benedixit Abraham /.../;/.../ vident tale sacrificium nunc offerri Deo toto orbe terrarum".

77 De civitate Dei XVI 22, PL 41, 500: "Ibi quippe primum apparuit, quod nunc a Christiaisis offertur Deo toto orbe terrarum".

73 Enarratio in Psalmum 106, 13, PL 37, 1427 = nota 75.

79 Epistola 140, 46, PL 33, 557: "Timentes enim Deur homines Veteris T'estamenti $/ \ldots /$, currebant cum sacrifici is ad templuli; et quatavis in figuram futuri sanguinis quo redempti sumus, tamen nescientes quid per eas praefiguraretur, cruentas victimas immolabant. Nunc vero in gratia Novi Testamenti, "qu1 timetis Deun laulate eum" /.../. Et paulo post, ut ostenderet sacrificium Novi Testanenti, quando illa fuerant cessatura, "Immola", inquit, "Deo sacripicium laudis"/.../. Salutare Dei Christus est". 
wego Testamentu". "To jest łasisa, darmo dana, nie ze wzglęiu na zasługi tego, kto spełnia akt oîarniczy, lecz dzlęki zmiłowaniu Tego, kto udziela łaski. Stąd dzlęki skladamy Panu Bogu naszemu. To jest wieliri sakrament w ofiorze Nowego Testamentu" 80 .

5. "Caro et sanguis Domini novum sacrificium" "Ciało i Krew Pańska jako nowa ofiara"

Na nowość ofiary Nowego Téstamentu jako odrębnej rzględem krwawych ofiar Starego Testamentu, które byìy jedynie obrazową zaporiedzia" 1 "znakien przyszłej Krwi, dzięki której zostaliśmy odkupieni"81, zwraca Augustyn uwage w takim wyjaśnien1u: "Oto pokarm dający życie wiecznel /.../. Przypatrzcie się więc pokorze: ponieważ człowiek spożywał chlei anielski /.../. 'Unizyz sanego siebie'/.../, aby już z Krzyża były nạm zalecone Clało 1 Krew Pańska jako nowa ofiara" 82 .

\section{6. "Sacrificium Dei" "Of 1 ara dla Boga"}

Na pytanle: Czym jest ofiara dla Boga? Augustyn odpowiada: "Możo właśnle to robimy, składamy na ołtarzu oflarę, kiedy wielbimy Boga / a... A gdybyś szukał kapłana, to jest on ponad niebiosami. Wstawia się za tobá Ten, który umarł za ciebie na ziemi"83. W innyil miejscu jest toz mora o "uświęceniu ofiary dla Boga" 84 .

80 Tamze, 48, PL 33, 558: "Haec est gratia, quae gratis datur non ileritis operantis, sed miseratione donantis.. IInc gratias agimus Domino Deo nostro".

81 Tariże, 46, PL 33, 557: "in figuram futuri sanguinis quo rederpti sumus".

82 Enarratio in Psalmum 33, 6, PL 36, 303: "Ecce cibus sempiternus /... Videte ergo humilitaten: quia panem Angelorum manducavit homo /.../. 'Ifumiliavit semetipsum'/.../ ut lam de cruce commendaretur nobis caro et sanguis Domini novum sacrificiurl".

83 Enarratio in Psalnun 94, 6, PL 37, 1220: "Sacrificiun Dei qu1d est? Forte hoc facimus modo, imponimus in ara sacrificiluil, guando Deum 1 audaus".

84 Serio 227, PL 33, 1100: "Deinde post sanct1ficationem sacrificil Dei, /.../ ubi i lipositum est primum illud sacrificium Dei et nos, id est signuar rei quod sumus; ecce ubi est peracta sanctificatio,/.../ dicimus orationen Dominicam". 


\section{7. "Sacriflcium/.../ Dominicae passionis" "ofiara /.../ Męki Paískiej"}

W świetle bardzo wyraźnego objawienia, przekazanego za pośrednictwem pouczonego i bardzo mądrego męza, "po przyjściu Chrystusa riały być zniesione wszystkie of 1 ary składane w czasach pogaństwa, a žodnie z poboźnością ludu, miała być składana Bogu jedynte opiara Męlri Pańsiriej"85.

\section{8. "Sacrificium Niediatoris" \\ "Ofiara składana przez Pośrednika"}

Eucharystia jest "Ofiarą składaną przez Pośrednika" za dusze zmarłych, jaik się wyraża św. Augustyn ${ }^{86}$. Tym zaś Pośrednikiem między Bogiem i ludźmi jest Chrystus.

\section{9. "Mirabile et caeleste sacrificium omni reverentia et devotione dignum" \\ "Przedziwna 1 niebiańska ofiara godna wszelkiej czci 1 pobożności"}

Elcharystia jest "przedziwna $i$ niebiańska ofiara godna wszelkiej czci i pobożności. Ty ją ustanowiłeś, o Panie, mój Boże, niepokalany Kapłanio, 1 poleciłeś ją składać na pamiątkę Trojej miłości"87.

\section{0. "Unum salutare sacripjcium" "Jedna zbawcza Ofiara"}

Eụcharystia jest "jednaz zbawcza ofiara" przodstawiana w obrazach $i$ zapowiadana przez skadane dawniej Bogu ofiary ze zwierzat osiarnych: "W owym czasie, kiedy zyz Dawid, składano Bogu ofiary ze zwierzat ofiarilycil. $̈$ idazlał on nasze przyszłe czasy /.../. Tante ofiary by ży obrazaui 1 zapowiedziani jednej

85 Sermo/de Veteri et Novo Testamento/36, 3, PL 39, 1816: "Quo facto mani iestissime revelavit/sc. vir doctus et praesagus/ post adventun Domint omnia abolenda esse gentilitatis sacrificium Deo Dominicao passionis pro religione populi deferendum".

86 De octo Dulcit11 quaestionibus. Quaestio 2, 4, PJ, 40, 158: "pro illis/sc. defunctorum anints/sacrificium Mediatoris offertur".

87 Nanuale 11, PL 40, 956: "mirabile et caeleste sacrificium omni reverentia et devotione dirnum, quod tu, Domine Deus melis, sacerdos tmaculate, Instituisti, et offerri praeceptsti in comenorationela tuae caritatis". 
zbawczej ofiary" 88 .

11. "Unicum Sacrificium"

"Jedyna ofiara"

Eucharystia jest "jedyną ofiara": "Potern doszła jedyna opiara $/ \ldots /$,której cienten były wszystkie tante ofiary. One jej nie usuwały, lecz zajowiadały jaz przez znaki"89.

12. "Unicum sacrificium pro salute nostra"

"Jedyna oftara dla naszego zbawienia"

"Ciało 1 Krew Chrystusa", jak wyjaśnia św. Augustyn, stanowią "jedyna ofiare dla naszego zbawienia" 90 .

\section{3. "Sacrificium corporis Christi"}

"Opiara Ciala Chrystusa"

Eucharystia jako "opiara Ciała Chrystusa" jest ofiara błagalniz w intencjach prywatnych, złozona przez jednego z kapłanów na prośbe byłego trybuna, niejaki ego Hesperiusza, o uwolniente zwierząt 1 sizu厶̇by w jego domu od cierpień $i$ udręk zadawanych im przez złe duchy: "Wybrał sie jeden, złożył tain ofiare Ciaza Chrystusa, modląc się, jak mógł, aby ustało owo udręczente. I zaraz ustało dziçki litościwemu Bogu" ${ }^{91}$. Tym sanym terninem określa św. Augustyn propozycję "składanta ofiary Ciała Chrystusa także za tych, którzy nie sa wcielent w Chrystusa" przez chrzest, "innowacją obcą praktyce kościelnej 1 słusznyn przepison", "nowyu czyli błęanyil poglądem"92.

88 Enarrationes in Psalmum 50, 21, PL 36, 598: "In illo tempore erat David, quando sacrificia victimarum animalium offerebantur Deo, ei videbat haec futura tcmpora./... Erant illa sacrificia figurata, praenuntiantia unum salutare sacrificiü".

89 Contra adversariun Legis et Prophetaruin I 37, PL 42, 624: "posteaquari venit unicuin sacrificium, cuius umbrae fuerunt illa omnia, non hoc improbantia, sed hoc significantia".

90 Contra Crcscontur Donatistam I 30, PL 43, 46a: "de ipso corpore et sanguine Domini, unico sacrificio pro salute nostria".

91 De civitate Dei XXII 8, 6, PL 41, 764: "Perrexit unus/sc. presbyter/, obtulit ibi sacrificium corporis Christi, orans quantum potult, ut cessaret 111 a vexatio: Doo protinus migerante cessavit". 
14. "Sacrificium corporis et sanguinis Christi" "Opiara Ciała i Krifi Chrystusa"

Eucharystia jest "oplara Ciała 1 Krwi Chrystusa": "Zachowując wiare katolicką 1 przepis kościelny, w żadnym wypadku nie pozwala sie na składanie oflary Ciała 1 Krwi Chrystusa za nie ochrzczonjcil jakiegokolwiek wieku" 93.

15. "Sacrificium corporis et sanguinis Domini" "Ofiara Ciala 1 Krwi Pańskiej"

Eucharystia jest "ofiarą Ciała 1 Krw1 Paískiej, Jaką znaJa wierni $i$ ci, którzy czytali Ewangelię. Ta ofiara jest obecnie rozporszecilniona na całym globie ziemskim" 94 .

16. "Sacrificium pretil nostri" "Ofiara naszogo Odkupienia"

Ducharystia jest "ofiara naszego Odkupienia"95, jak sie

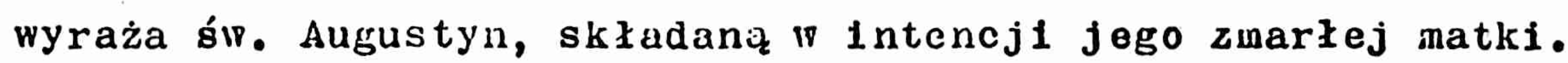

\section{7. "Sacrificium salutare"} "Ofiara zbawcza"

Eucharystia jest "ofiaraz zbawienia": "Nie nalezy natomlast wątpié, żę z!narll doznaja pomocy dzięki modlitwoin świętego Kościoła, dzięki ofierze zbawczej 1 jałmuźnom, jakłe składa się za ich dusze" 96 .

si placet, etiam censorem, si parum fuerat habere doctorem, ut sacrificium corporis Christi etiam pro his offeras, qui Christo non sunt incorporati. Iem quippe tam novan, atque a disciplina ecclesiastica et a regula veritatis alienam,cum libris suis auderet inserere, non ait "Puto", non alt "bxistino", non ait "Arbitror", non ait saltem "Suggero", vol "Dico", sed "conseo", ut offenderemur novitate seu perversitate sententiae, terreremur auctoritate censurae".

93 De antra et eius origine $I$ 13, PL 44, 481: "salva fide catholica et ecclesiastica regula, nulla ratione conceditur, ut pro non baptizatis cuiuslibet actatis hominibus offeratur sacrificium corporis ot sanguints Christi".

94 Enarrationes in Psalnum 33, 5, PL 36, 303: "sacrificium corporis et sangulnis Domini, quod fideles norunt, et qui Evangelium legerunt, quod sacrificium nunc diffusuin est toto orbe terrarun".

95 Confessiones $\operatorname{IX} 12,32, P L, 32,777$ : "cum offerretur pro ea sacrificiul pretil nostri".

96 Sermo 172, 2, PL 38, 926: "Orationibus vero sanctae Ecclesiae, 
18. "Sacrificium verum quod fideles norunt" "Prawdziwa oflara, jakaz zaja wiorni"

Eucharystia jest "prawdziwa ofiara, jaka znaja wierni 1 która była zapowiadana w obrazach" ${ }^{97}$.

19. "Verum et unicum sacrificium pro peccatis" "Prawdziwa 1 jedyna oflara za grzechy"

Eucharystia jest "prawdziwa 1 jedyną ofiara za grzechy", czyli ofiara przobłagalną: "ofiary za grzechy nazywano w Prawie grzechami. Te wszystkie ofiary były obrazami Ciała Chrystusa. To jest prawdziwa 1 jedyna ofiara za grzechyn98.

\section{0. "Summum verumque sacrificium" "Największa 1 prawdziwa ofiara"}

Eucrarystia, "codziennie sprawowany sakrawent" 1 "opiara Kościoła", jak chciał Jezus Chrystus, jako kapłan, i jako oPlarnik, sam równiez jako ofiara, stanowi "największa 1 prawdziwa ofiarę", przed którą "ustąpiły wszystkie ofiary fałszywe" 99 .

\section{1. "Singulare sacrificlum pro peccatis"} "Szczegól lna ofiara za grzechy"

Eucharystia jest "szczególną ofiarą za grzechy", czyli ofiara przebłagalną. Grzechy "zostają nan odpuszczone dzięki szczególnoj ofierze za grzechy", gdyż "Chrystus stał się ofiaraz ga grzechy "100.

et sacrificio salutari, et eleemosynis, quae pro eorum /sc. mortuorum/ spiritibus erogantur, non est dubitandum, mortuos adiuvari".

97 Enarrationes in Psalmum 39, 12, PL 36, 441: "quando adhuc sacrificium verum quod fideles norunt, in figuris praenuntiabatur".

98 Contra duas epistulas Pelagianorum III 16, PL 44, 600: "sacrificia pro peccatis peccata appellabantur in Lege, quae omnia figurae fuerunt carnis Christi, quod est verum et unicum sacrificium pro peccatis /.../; et dimittuntur nobis per singulare sacrificiun pro peccatis /.../; videtur intelligi /.../ Christum factum sacrificium pro peccatis".

99 De civitate Dei X 20, PL 41, 298: "Christus Iesus/.../ sacerdos est, ipse offerens, ipse et oblatio/.../ sacramentum quotidianum esse voluit Ecclesiao sacrificium $/ \ldots /$. Ilule sumio veroque sacrificio cuncta sacrificia falsa cessorunt.

100 Contra duas eplstulas pelagianorum III 16. PL 44. 600: tekst 
22. "Unum verum et singulare sacrificium" "Jedna pruwdziwa i szczególna ofiara"

Eucharystia jest "jedną prawdziwą i szczególną ofiaraz zapowiedzianą przedtem wieloma obrazami ofiar" ${ }^{101}$.

23. "Verissimum et singulare sacrificium" "Najprawdziwsza i szczególna ofiara"

Eucharystia jest "najprawdziwszą i szczególná ofiarą": "w czasie składania tej najprawdziwszej i szczególnej ofiary otrzymujemy wezwanie do tego, aby składać dzięki Panu Bogu naszemu"102. Jest to téz ofiara dziękczynna.

24. "Universale sacrificium"

"Opiara powszechna"

Eucharystia jest "ofiara powszechną" w takim znaczeniu: "Samo odkupione państwo, tj. zgromadzenie i społeczność świetych, ofiara powszechna, jest składana Bogu przez Wielkiego Kapłana, który sam także ofiarował się za nas w swej Męcen103. 25. "Sacrificium Christianorum"
"Opiara chrześcijan"

Eucharystia jest "ofiarą chrześcijan": "Taka jest ofiara chrzescijan: 'wielu jest jednym ciałem w Chrystusie'. Kośció powtarza składanie tej ofiary w sakramencie ołtarza, jaki znaja wierni"104. "Na każuym miejscu jest składana ofiara chrześciJan" 105 .

Jak przypis 98.

101 Contra adversarium Legis et Propinetarum I 37, PL 42, 624: "sic unum verum et singulare sacrificium multis est antea sacrificium significatum piguris".

102 De spiritu et littera 18, PL 44, 211: "Unde et in ipso verissimo et singulari sacrificio, Domino Deo nostro agere gratias admonemur".

103 De civitate Dei X 6, PL 41, 284: "profecto efficitur, ut ipsa redempta civitas, hoc est congregatio societasque sanctoruin, universale sacrificium offeratur Deo per sacerdotera nagnum, qui etiali se ipsum obtulit in passione pro nobis".

104 Tanze: "Hoc est sacrificium Christianorum: 'multi unum corpus in Christo'. (quod etiali jacramento altaris fidelibus noto frequentat Ecclesia".

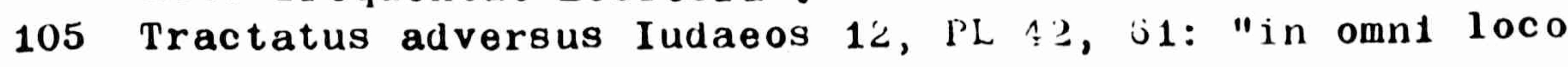


Nie moźna składać jej za tych, którzy nie zostali ochrzczeni: "Nie sądź, nie mów, nie ucz, że należy składać ofiarę chrześcijanza tych, którzy wyszli z ciała jako nie ochrzczeni, jeśli chcesz byc katolikiem"106.

\section{6. "Christianorum sacrificia" \\ "Ofiary chrześcijan"}

"Na pochwałe zasługuja ofiary chrzesicijan, które trwaja dzięki niewinności Chrystusa jakio niewinnego Baranka. Te ofiary były zapowiedziane w znakach przez dary ofiarne samego Abla pochodzace z jego owiec"107.

27. "Ecclesiae sacrificium" "Ofiara Koscioła"

Św. Augustyn wyjaśnia, że Jezus Chrystus jako Pośrednik między Bogiem i ludźmi, kapłan, który składa ofiarę, i ofiara, "chciał, aby sprawowany codziennie sakrament tej rzeczywistości był ofiarą Kościoła"108.

\section{8. "Nostrum sacrificium"}

"Nasza ofiara"

Eucharystia jest znakiem jedności wszystkich wiernych w Kościele: "Głowa tego ciała jest Chrystus. Jedność tego ciała jest zalecaná przez nasza ofiarę"109.

29. "Sacrificium pacis, sacrificium caritatis, sacrificium corporis sui norunt fideles" "Ofiare pokoju, ofiare miłości, ofiare Jego Ciała znaj a wierni"

Eucharystia jest "ofiarą pokoju, ofiarą miłośc1, ofiarą

offerri sacrificium Christianorum".

106 De anima et elus origine III 18, PL 44, 520: "No1i credere, nec dicere, nec docere, Sacrificium Christianorum pro is qui non baptizati de corpore exirent, offerendum, $s i$ vis esse catholicus".

107 Dialogus quaestionum 47, PL 40, 748: "Christianorum sacrificia, quae ex innocentia Christi innocentis agni constant, laudantur, quae significabant ipsius Abel ex ovibus munera".

108 De civitate Dei X 20, PL 41, 298: tekst wocie 62. 109 Epistola 187, 20, PL 33, 839: "Huius corporis caput est 
Ciała Chrystusa, jaka znają wierni"110.

30. "Peracti elusdem sacrificil memorla" "Wspomnienie dokonanej już raz tej samej ofiary"

Eucharystia jest wspomnieniem ofiary Ciala 1 Krwi Chrystusa złożonej na krzyżu: "Dlatego chrześcijanie obchodza jeszcze wspounienie dokonanej juz raz tej samej ofiary przez składanie najświętszej oflary i uczestnictwo w przyjmowaniu Ciała 1 Krwi Chrystusa"111.

\section{1. "Sacrificium panis et vini" "Oflara chleba 1 wina"}

Eucharystia jest "ofiara chleba 1 wina" o wymlarze trynitarnym: "Kościóz święty katolick1 teraz, to jest w okresie Nowego Testamentu, po całyn globie zienskim, w wierze 1 miłości, nie przestaje składać Mu wazcznośc1 z ojcem 1 Duchem Swiętym/Bóg jako Słowo, które stało się ciałen/, z którymi ma jedno bóstwo, ofiary chleba 1 vina"112.

\section{2. "Sacrificium laudis" "Ofiara pochwalna"}

Eucharystụa jest "ofiara uwielbienia": "Kościół, który dzięki całkiem pewnemu następstwu biskupów trwa ciągle od 1ch /tj. apostołów Andrzeja $i$ Jana/ czasów aż do naszych czasów, składa Bogu ofiarę pochisalną w Ciele Chrystusa"113.

Christus, huius corporis unitas nostro sacrificio commendatur".

110 Enarrationes 2 in Psalmur 21, 28, PL 36, 178: "Sacrificiurn pacis, sacrificium caritatis, sacrificium corporis sui norunt fidoles".

111 Contra Faustum Manichaeum 17, PL 42, 382: "Unde 1am Christiani, peracti eiusdem sacrificil memoriam celebrant, sacrosancta oblatione et participatione corporis et sanguinis Christi".

112 De fide ad Petrum sive De regula verae fidei 19, PL 40, 772: "et cui nunc, id est teilpore Novi Testamenti, cum Patre et Spiritu sallcto, cum quibus $111 i$ est una divinitas,sacrificium panis et vini in fide et caritate, sancta catholica Ecclesia per universuru orbcrl terrae offerre non cessat".

113 Contra adversarium Legis et Prophetarum I 38, PL 42, 626: "Ecclesia, quac ab 11 lorun/sc. apostolorum Andreae Ioanniscue/ lempoibus per episcoporum successiones perseverat. 
33. "Sacrificiun gratuitum, gratia datum" "Ofiara pochodząca z łaski, darmo dana"

Eucharystia jako ofiara uvielbienia 1 dziękczynienia jest "ofiara pocinodzącá z łaski, darmo daną", jak o niej móri następuJąca inwokacja: "O ofiaro pochodząca z łaski, darmo danal Nie kupiłem przecieź tego, co man złożyć w ofierze, lecz Ty mi dałeś, bo tego'nie miałew. 'Złóz Bogu ofiaré pochwalną?. A tozłoźenie ofiary pochwalnej jest składaniem dziękczynienia Temu, od którego masz wszystko, cokolwiek masz dobrego, a dzięki którego miłosierdziu zostaje ci odpuszczone wszystko, cokolwiek masz w sobie złego"114.

34. "Praeclarissimum atque optimum sacrificium" "Najwspanialsza i najlepsza ofiara"

Eucharystia jest "najwspanialsza i najlepsza ofiarą", jaka my sami jestesmy dla Boga w tejemnicy składania Mu naszych oflar dzięki duchowej łączności z całą społecznością naleźąca do Chrystusa: "My sami, to jest Jego państwo, jesteśmy najwspanialsza 1 najlepsza ofiara dla Nicgo. Tajemnice tej rzeczywistości obchodzimy przez sirładanie naszych ofiar, jakie saz znane wiernym"115. "My sami jesteśmy takaz oflara w całości"116.

\section{5. "Sacrificium vespertinum" "Ofiara wieczorna"}

Eucharystia jest "ofiarą wieczorną", która jako "oîiara pochwalna" w Nowym Testamencio nastapiła po "krwawych ofiarach"

et immolat Deo in corpore Christi sacriflctum laudis". Por. tanże I 37, PL 42, 624: "Quod est autem sacratius laudis sacrificium, quan in actione gratiarum?" Por. takio Enarrationes in PSalmum 49, 21, PL 36, 578: "Et haec immolatio sacrificii laudis, gratias agere illi a quo habes, quidquid bont habes".

114 Enarrationes in P'salmum 49, 21, PL 36, 578: "O sacrificium gratuitum, gratia datum! Non quidem hoc emi, quod offeram, sed tu donasti, nam nec hoc haberen. 'Inmola Deo sacrificium laudis'. Et haec immolatio sacrificii laudis gratias agere illi a quo habes quidquid boni habes, et cuius misericordia tibi dinititur quidquid tuum isali habes".

115 De civitate Dei XIX 23, 5, PL 41, 655: "praeclarissimum atque optimum sacrificium nos ipsi sumus, hoc est civitas eius, cuius rei mystcrium celebramus oblationibus nostris, quae fidelibus notae sunt".

116 T'anże, X 6, PL 41, 284: "totlin sacrificlum 1ps1 nos sumus". 
Starego Testamentu"117: "Dziwisz się, że człowiek dochodzi do zycia wiecznego? Dziw się raczej, że Bóg za ciebie poszedł na śmierć. Dziwisz się, a nie wierzysz? 'Słowo stało się ciałem i zamieszkało wśród nas'. Oto skąd wzięza swój początek ofiara wieczorna. Trzymajmy się Go mocno: niech będzie z nami złożony w ofierze Ten, który za nas się ofiarował. Tak bowiem przez ofiarę wieczorniz ustaje stare życie, a nowe powstaje dzięki jasności"118.

IV. INNE OKREŚLLNIA EUCHARYSTII

Po scharakteryzowaniu trzech najważniejszych nazw eucharysti1: "eucharistia", "sacramentum" 1 "sacrificium", wymienimy z kolei i inne najciekawsze jej augustyńskie określenia.

\section{1. "Sancti altaris oblatio" \\ "Ofiara złożona na świętym ołtarzu"}

Eucharystia jest "ofiarą składana na świętym ołtarzu": "Poświęca się wszystko, co składa się Bogu w ofierze, szczególnie ofiare złożoną na świętyrn ołtarzu. Przez ten sakrament ogłasza sie publicznie owo nasze najważniejsze przyrzeczenie, moca którego przyrzekliśmy uroczyście, że będziemy trwać w Chrystusie, rozunie siz̧ w organicznym zwiczzku z Ciałer Chrystusa. Sakramentem tej rzeczywistości jest to, że 'wielu nas jest jednym chlebem $i$ jednym ciałen' /1 Kor 10, 17/ w Chrystusio"119.

117 Por. noty 79 i 88 .

118 Serino 342, 5, PL 39, 1504: "Miraris si homo perveniat ad vitam aeternam? mirare potius quod Deus pro te pervenit ad morter. Miraris, non credis? 'Verbum caro factum est, et habilavit in nobis'. Ecce unde factum est sacrificium vespertinum. Inhaerearius illi: nobiscum offeratur, qui pro nobis oblatus est. Sic enim vespertino sacrificio vita vetus interficitiur, ot dilucido nova oritur".

119 Epistola 149, 15, PL 33, 637: "Voventur autem omnia quae offeruntur Deo, maxine sancti altaris oblatio; quo Sacramento praedicatur nostrum illud votum maximum, quo nos vovimus in Christo esse mansuros, utique in compage corporis Christi. Cuius rei sacrabentum est, quod unus panis, unum corpus mul$t 1$ sumus $/ 1$ Cor $10,17 / "$. 
2. "Oblationes nostrae quae fidelibus notae sunt" "Nasze ofiary, jakie saz znane wiernym"

Eucharystia są równiez "nasze ofiary znane wiernym"120.

3. "Sacrosancta oblatio"

"Najświętsza ofiara"

Eucharystia jest według Augustyna "najświętszą ofiara"121.

\section{4. "Opferre"}

"Składanie ofiary"

o częstotliwości składania ofiary eucharystycznej przez kapłanów Biskup IIppony inforauje, że: "w jednym miejscu nie opuszcza się żadnego dnia, w któryn by nie. składano ofiary, w Innyn miejscu składa sie ofiare tylko w sobote 1 w niedzie1ę, a gdzie indziej tylko w niedzielę"122.

5. "Immolare"

"Składanie ofiary"

Sw. Augustyn tak poucza o "składaniu ofiary" eucharystycznej za nas codziennie: "Chrystus raz za nas został złoźony w ofierze, jakby nas codziennie odnawiał Ten, który odnowił nas przez swoją pierwszą 'taskę" udzieloną nam w czasio chrztu ${ }^{123}$.

120 De clvitate Dei XIX 23, 5, PL 41, 655: tekst nota 115.

121 Contra Faustum Manichaeum 17, PL 42, 382: "Unde iam Christiani, peracti eiusdem sacrificii memorian celebrant, sacrosancta oblatione et participatione corporis et sanguinis Christi".

122 Epistola 54, 2, PL 33, 200: "alibi nullus dies praetermittitur, quo non offeratur, alibi sabbato tantum et dominico, alibi tantum dominico".

123 Enarrationes in Psalmum 75, 15, PL 36, 966: "Et semel nobis Christus iminolatus est, quando credidimus, /.../ quotidie nois imolatur, quasi quotidie nos innovet, qui prima gratia sua nos innovavit". 


\section{6. "Benedictio Christi" \\ "Błogosławieństwo udzielone przez Chrystusa"}

Ten termin ma związek $z$ obrzędem konsekracyjnym $w$ ofierze eucharystycznej: "Nie każdy bowiem chleb, lecz ten, który otrzymuje błogosłalpieństwo udzielone przez Chrystusa, staje się Ciałem Chrystusa"124.

7. "Celebratio corporis et sanguinis Domini" "Sprawowanie Ciała 1 Krwi Pańskiej".

I ten termin ${ }^{125}$ ma zwiazzek z obrzędem konsekracyjnym, podobnie jak termin "sprawowanie sakramentów" /celebratio sacramentorum/, o czym była już mowa ${ }^{126}$.

\section{8. "Consecratio"}

"Konsekracja" lub "Święte Przeistoczenie" albo "Przemiana chleba i wina w Ciało 1 Krew Chrystusa"

To jeszcze inna u siw. Augustyna náwa obrzędu konsekracyjnego: "Nasz chleb i kielich, nie jakikolwiek/.../, lecz po pewnej konsekracji staje sie dla nas mistyczny /.../. Dlatego to, co w ten sposób nie staje się takie, chociaż jest chlebem i kielichem, jest posilnym pożywieniem, nie sakramentem $\sigma$ znaczeniu religijnym, chyba źe tym chlebem i kielichem jest to, co błogosławimy 1 dzięki składany Panu" ${ }^{127}$.

9. "Cena consecruta" "Wieczerza konsekrowana" lub "Uczta święta" albo "Uświącony posiłek"

Ten ternin wiąże się u Doktora Laski z lïieczerzą Paŕska,

124 Serino 234, 2, PL 38, 1116: "Non enim omnis panis, sed accipiens benedictionem Christi, fit corpus Christi".

125 De doctrina christiana III 13, PL 34, 71: "celebratio corporis et sanguinis Dorini".

126 Por. notę 72 .

127 Contra Paustun Manichaeum 13, Pl, 42, 379: "Noster autem panis et calix, non quilibet $/ \ldots /$, sed certa consecratione mysticus it /.../. Proinde quod non ita fit, quamvis sit panis et callx, alimentum est refectionis, non sacramentum religionis, nisi quod benedicimus, gratiasque agimus Doinino". 
która dla słuchaczy jego kazania jest posiłkiem spożywanym codziennie dzięki wierze: "My, moi bracia, zostaliśmy wezwani na uczte /por. Ap 19,9//../ Wieczerze konsekrowaną podał /Chrystus Pan/ swoim uczniom, lecz my nie byliśmy przy stole na tamtej uczcie; jednak dzięi wierze codziennie spożywamy tę Wie$\operatorname{czerze}^{128}$

10. "Ministerium dominici corporis"

"Postuga Ciała Pańskiego" lub "Korzystanie z posługi Ciała Panskiego"

Tak nazywa św. Augustyn korzystanie z eucharystii, któro w jego czasach było ogólnie przyjętą praktylsá kościelną: "Przyjdzie bowiem wilk, nie człowiek, lecz diabeł. Namawiał on do odstępstwa najczęściej tych wiernych, którym zabrakło na codzień korzystania z posługi Ciała Pańskiego"129.

\section{1. "Sanctificatio" "Uświęcenie"}

Tym terminem posługuje się Biskup Hippony, gdy mówi - "przygotowaniu uświęcenta" 1 o samym "uświęceniu ofiary dla Boga": "Dlatego uważam, ze Apostoł nakazał, aby w czasie przy-

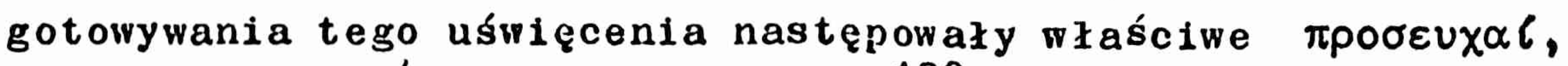
to jest orationés, czyli modlitwy"130. "Nastepnie po uśriecceniu ofiary dla Boga, poniewaź chciał, zebyśmy sami stanowili Jego ofiare, co już zostało wyjaśnione, gdy została złożona najpierw tanta, opiara dla Boga, $i$ my, to jest znak tej rzeczywistości, Jakim jesteśmy, oto gdy zostało dokonane uświecenie, odmawiamy modlitwę Pańska /.../. Po niej mówi sie 'Pokój z wani' 1 chrześcijanie całują się w świętyın pocalunku. Jest to znak pokoju

128 Sermo 112, 4, PL 38, 645: "Nos, Pratres me1, ad cenam vocati /... Conam manibus suis consecratam discipulis dedit: sed nos in 1110 convivio non discubuinus; et tamen cenarn ride quotidie manducamus".

129 Epistola 228, 6, PL 33, 1016: "Veniet enim lupus, non homo sed diabolus, qui plerulque fidoles apostatas esse persuasit, quibus quotidianun mysterium Doninici corporis defuit".

130 Epistola 149, 15, PL 33, 637: "Ideo in huius sanctificationis praeparatione existimo Apostolun iussisse propriae

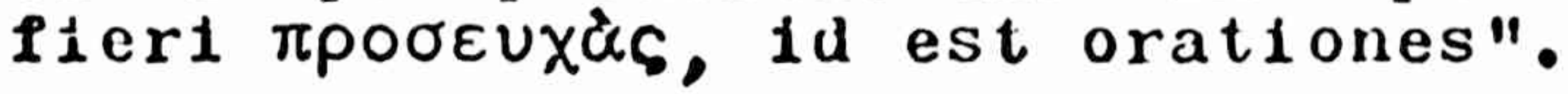


/.../. Wielkie więc sa to sakranenty i to bardzo wielirie $/ \therefore . /$. oto przyjmuje się, spożywa się /.../ Ciało Chrystusa"131.

\section{2. "Sacra mysteria"}

"Sivięte misteria" albo "Święte tajemice"

Nazwa "święte misteria" okresia św. Augustyn ofiare eucharystyczná, zwłaszcza modlitwę eucharystyczną: "W czasie świętych misteriów otrzymujeny nakaz wzniesienia w górę serca /.../, abyśmy dzięki składali Panu Bogu naszemu. Ciągle borilem otrzymujemy przypomnienie o tym, bo to jest godne, bo to jest sprawiedliwe. Przypominasz sobie, skąd są te słora" ${ }^{132}$.

13. "Intimum fideliun mysterium" "Misterium dostępne dla wiernych"

Eucharystia jest "misterium dostępnym dla wiernych": "pokolenie ludzi poiożnych 1 świętych /.../ doskonalazc się w tym swoim poczuciu/pobozności i świętośc1/, cokolwi eir dobrego robi, robi to dla pana; stąd to ma miejsce składanie dziękczynienıa, które powtarza się przez misterium dostępne dla wiernych"133.

14. "Mensa"
"Stół"

A. Stół słowa Bożego

"Cibus noster quotidianus in hac terra, serwo Dei, qui semper erogatur in Ecclesia"

"Naszym pokarmem codziennym na tej ziemi - stowo Boże, które ciaggle jest podawane w Kościele"

Św. Augustyn wyjaśnia, że z ołtarzem/altare/ ma zwį̨zek pókarm przeznaczony na cocizień dla wiernych 1 ochrzczonych,

131 Sermo 227, PL 38, 1100: por. pierwsza część tego tekstu nota 84/: "Post ipsam dicitur, 'Pax vobiscum' et osculantur se Christiani in osculo sancto. Pacis signum est $/ . . . /$. Magna crgo sacramenta, et valde magna /.../ Ecce accipitur, comeditur, consumitur /.../ corpus Clıristi".

132 De bono viduitatis 16, 20, PL 40, 443: "inter sacra mysteria cor habere sursum iuberaur $/ . . . /$. Domino Deo nostro gratias agamus. Hoc enim continuo commonetiur, quia hoc dignum est, hoc iustum est. Recordaris haec verba unde sint".

133 Epistola 140, 70, PL 33, 569: "generatio scilicet piorum atque sanctorum $/ \ldots$. . In quo affectu proficiens, quidquid bo- 
którym jest podawane przez Kościół zarówno słowo Boże, jak i cucharystia: "Jaki jest ten chleb i dlaczego nazywa sie chlebem powszednim? Ten chleb jest konieczny. Bez niego przeciez nie moźemy źyć. Bez chleba nie możemy żyć. Bezwstydnością jest, abyś prosil Boga o bogactwo, a nie jest bezwstydnościa, abyś prosiz o chleb powszedni. Jedno jest dla ciebie powoden do chełplirości, drugie jest dla ciebie środkiem do życia. Poniewaź jednak ten chleb jest podawany w sposób widzialny 1 dotykalny zarówno dobrym, jak i złym, jest chlebem porszednim, o który prosza dzieci. Jest nim słowo Boże, które podaje się nam codziennie. To jest nasz chleb powszedni. Dzięki niemu żyją nie ciaza, lecz dusze. Konieczny jest on takze teraz dla nas robotników w winnicy. Jest pokarmem, nie zapłata. Robotnikowi bowiem dwie rzeczy jest winien ten, kto go wynajmuje do winnicy: pokarm, aby nie osłabł, 1 zapłate, aby sie z niej cieszył. Naszym pokarmem codziennym na tej ziemi - słowo Boże, które clągle jest podawane w Kościele. Nasza zapłata po pracy nazywa się zyciem wiecznyin. Jeśl noże znowu w tym naszym chlebie powszednim rozróźniasz to, co przyjmuja wierni, co mają zamiar przyjąć ochrzczeni, to dobrze modlimy się i mówimy: chleba naszego powszedniego daj nam dzisiaj', abyśmy tak żyli, żebyśny nie byll odłączeni od tego ołtarza"134.

ni facit, Domino facit; unde est actio gratiarum, quae intimo fidelium mysterio celebratur".

134 Sermo 56, 10, PL 38, 381: "Quis est iste panis? et quare dicitur quotidianus? Et iste necessarius est: etenim sine illo vivere non possumus; sine pane non possumus. Impudentia est, ut a Deo petas divitias: non est impudentia, ut petas panem quotidianum. Aliud est unde superbias, aliud est unde vivas. Tamen quia iste panis visibilis et tractabilis datur et bonis et malis, est panis quotidianus quem petunt filii. Ipse est serilo Dei, qui nobis quotidie erogatur. Panis noster quotidianus est: inde vivunt non ventres, sed mentes. Necessarius est nobis etian nunc operariis in vinea; cibus est, non merces. Operario enim duas res debet, qui illum conducit ad vinear, cibum, ne deficiat; et merceder, unde gaudeat. Cibus noster quotidianus in hac terra, serno Dei, qui semper erogatur Lcclesia: merces nostra post laborem vita aeterna nominatur. Iterum in isto pane nostro quotidiano si intelligas quod fideles accipiunt, quod accepturi estis baptizati; bene roganus et dicimus, 'panem nostrum quotidianum da nobis hodie': ut sic vivamus, ne ab 1110 altari separemur". 
B. Stóz eucharystii

a/ "Magna mensa" "Stóz wielki"

"Czym jest ten Stół wielki, jeśli nie stołem, skąd otrzymujemy Ciało Chrystusa 1 Krew?"135

\section{b/ "Mensa potentis" "Stóz Mocarza"}

"îlecie, czyn jest stół Mocarza. Tan jest Ciało i Krew Chrystusa /.../ dla zbudowania ludu i utwierdzenia wi ary"136

\section{c/ "Mensa Christi"} "Stóz Chrystusa"

"Pyszni /.../ bogacze /.../ zostali przyprowadzeni do stołu Chrystusa. Otrzyrujua też cząstkę z Jego Ciała 1 Krw1. Lecz tylko adoruja, nie nasycaja sie, ponieważ nie naśladuja /.../. Oni także przycinodzá do stołu, spożywaja 1 adorują. Nie nasycają się jednak, ponieważ nie pragną usilnie sprawtedliwośc1: Tacy bowiem będą nasyceni" 137 .

d/ "Mensa Ipsius" "Jego stóz"

"Chrystus karini codziennie. Jego stolem jest ów stół ustawiony w środku" 138 .

135 Sermo 31, 2, PL 38, 193: "Quae est magna mensa, n1s1 unde accipimus corpus Christi et sanguinem?"

136 In Ioannis Evangeliuri 47,2, PL 35, 1733: "Mensa potentis quae sit, nostis; ibi est corpus et sanguis Christi /... / ad aedificanáan plebem et asserendam fidem".

137 Epistola 140, 66-67, PL 33, 566-567: "divites/.../ superbi /.../ adducti sunt ad mensan Christi, et accipiunt de corpore ot sanguine eius; sed adorant tantuli, non etian saturantur, quoniam non imitantur /..../ et ipsi veniunt ad mensam, manducant et acorant; non tamen saturantur, quia non esuriunt et sitiunt iustitiam; tales enim saturabuntur".

138 Sermo 132, 1, PL 38, 735: "Per istos dies magistri pascunt, Christus quolidie pascit, monsa lpsius est illa in medio constituta". 
e/ "Christi mensa"

"Stół Chrystusa"

"Mieć wspólny z kimś stół Chrystusa"139.

f/ "Mensa Domini"

"Stół Pański"

"Przystąpić do stołu Pańskiego"140. "Spożywać pokarm ze stołu Pańskiego"141.
g/ "Domini mensa"
"Stół Pański"142
$\mathrm{h} /$ "Mensa dominica
"Stó́ Pański"

"Przystępujecie już do stołu Pańcklego. Spożywacte Ciało Chrystusa. Pijecie Jego Krew"143.

15. "Cena"

"Wleczerza" albo "Uczta"
a/ "Dominica cena"
"Vi eczerza Pariska"

"Do samej Wieczerzy Pańskiej przystąplł także/Judasz/. /.../. Piotr otrzymaz na życie, Judasz na śmieré $/ \ldots .$. . Dobry pokarm ożywia dobṛych, uśmierca złych"144.

\section{b/ "Cena Domini" \\ "Uczta Paríska"}

"Po odbytej już wieczerzy, po ofiarowaniu się Chry-

139 Por. Sermo 164, 11, PL 38, 900: "communicares cum 11lo Christ1

140 Por. Sermo 77, 4, PL 38, 485: "Ad mensan Domini accesserunt"; Sermo 137, 2, PL 38, 735: "ad mensam Domini lam acceditis"; Sermo 21, 5, PL 38, 145: "fidelis vocaris, accedens ad mensan Domini tui, respondens ex fide verba fidei".

141 Por. De Pide et operibus 9, PL 40, 202: "tunc de mensa Domini manducent".

142 Por. Epistola 36, 24, PL 33, 147; Epistola 149, 15, PL 33, 636.

143 Sertu 132, 2, PL 38, 735: "ad mensam Dominicam iam acceditis, et carnem Christi manducatis, et sanguinem biblitis. Por. Sermo 372, 2, PL 30, 1662: "de mensa Dominica".

114 In Ioannis Evangeitum 50, 10, PL 35,.1762: "Ad 1psan dominicam cenam pariter accessit /... Petrus enim accepit ad vitan, Iudas ad mortem $/ \ldots . /$, cibus bonus bonos vivipicat, malos mortificat". 
stusa, po przekazaniu polecenia odbywania irieczerzy Pańskiej, Jalkit znaja wierni, utrwalonej rekani 1 potwierdzonej ustami Pana, po zmartwychwstaniu Chrystusa zostali posłani apostołowie, doktórych przedtem zostali poszani prorocy. Przyjdźcie na ucztę!" 145

\section{c/ "Cena Christi" \\ "Uezta Chrystusowa"}

"Prorocy zapraszaja na Chrystlisowa ucztę"146.

16. "Sptritualis alimonia"
"Pożyienie dla duszy"

"Wierni znaja taḱze pożyienie dla duszy, jakie/.../ mają przyjmować z ołtarza Bożego"147.

17. "Cibus sempiternus"

"Pokaral dający życie wieczne"

"Oto pokarm dający życie wieczne!"148.

18. "Panis angelorum"

"Chleb aniołów" lub "Chleb należący do aniołów" albo "Chleb anielski"

"Lecz, aby człowiek spożywał chleb aniołów, Pan aniołów stał się człowiekich"149. "Człowiek spożywał chleb aniołów"150.

145 Sermo 112, 1, PL 38, 643: "Parata enim cena, immolato Christo, post resurrectionem Christi commendata quam sciunt fideles, cena Doinini, eiusque manibus et ore firmata, missi sunt Apostoli, ad quos missi fuerunt ante Prophetae. Venite ad cenam".

146 Sermo 112, 1, PL 38, 643: "Propnetae invitant ad cenam Christi.

147 Sermo 57, 7, PL 38, 389: "Norunt etiam spiritualem alimoniam fideles, quam/.../ accepturi de altari Def".

148 Enarrationes in Psalmum 33, 6, PL 36, 303: "Lcce cibus sem-piternus"。

149 Sermo 130, 2, PL 38, 726: "Sed ut panem Angelorum manducaret homo, Dominus Angelorum factus est homo".

150 Enarrationes in Psalmurn 33, 6, PL 36, 303: "panem Angelorum manclucavit homo". 
19. "Panis caeli"

"Chleb z nieba"

"Kto jest chlebem z nieba, jeśli nie Chrystus?"151

20. "Panis altaris"
"Chleb z ołtarza"

"Pan aniołór stał się człoriebien. Bo jeśliby nie stał się tą obecną rzeczywistością, nie mielibyśmy Jego Ciała, nie spożywal ibyśmy chleba z ołtarza"152. "Przez chleb przeznaczony na codzień powinniśmy rozumieć ten chleb, który macie zamiar przyjạć z ołtarza"153.

\section{1. "Panis sanctificatus" "Chleb uświ gecony"}

"Ten chleb, jaki widzicie na ołtarzu, uświçcony przez Słowo Boże, jest Chiałem Chrystusa. Ten kielich, rozumie się, zawartość kielicha, uświęcony przez Słowo Boże, jest Krwił Chrystusa" 154

22. "Quotidiana medicina Domini corporis" "Lekarstro Ciaza Pańskiego na codzień"

"Jeśli jednak grzechy nie są tak wielkie, aby ktoś był osazdzony jak o podlegający skazaniu na wykluczenie ze społeczności, to nie powinien powstrzymywać się od Lekarstwa Ciała Pańskiego na codzieí"155. "W okresie okazywania miłosierdzia w Kościele Bóg postanowił dać Lekarstwo na codzień po to, abyśmy mówili: 'Odpuść nam nasze winy, jako i my odpuszczamy naszym

151 Sermo 130, 2, PL 38, 726: "quis est panis caeli, nisi Christus?"

152 Sermo 130, 2, PL 38, 726: "Dominus Angelorum factus est homo. Si enim hoc non factus esset, carnein ipsius non haberemus, panen altaris non manducaremus".

153 Sermo 59, 6, PL 38, 410: "quotidianum panem 1llum intell1gamus, quem accepturi estis de altari".

154 Sermo 227, PL 38, 1099: "Panis ille, quea videtis in altari, sanctificatus per verbum Dei, corpus est Christi. Calix ille, imo quod hubet cai ix, sanctificatum per verbum Dei, sanguis est Christi".

155 Epistola 54, 4, PL 33, 201: "Ceterun peccata si tanta non sunt, ut excommuntcandus quisqueludicetur, non se debet quotidiana medicina Dorini corporis separare". 
winowajcom' / Mt 6, 12/, abyśmy z twarzą obmyta tymi słowami przystępowali do ołtarza 1 abyśmy po obmyciu twarzy tymi słowami mieli udzial Ciele Chrystusa i Krwi"156.

23. "Salubris refectio"

"Posiłek zbawczy" albo "Posiłek dający zbawienie"

Eucharyst1a jest posiłkiem dla osiagnięcia zbawienia: Chrystus "ze swojego Ciała 1 Krwi dał nan zbawczy Posiłek"157."

24. "Communicatio doninici corporis"

"Udział " przyjmowaniu Ciała Pańskiego" albo

"Przyjmowante Ciała Pańskiego"

Sw. Augustyn wspomina, że jego matka przyjmowała Ciało Pańskie: "tam odbywazo sie przyjmowanie Ciała Pańskiego"158

25." "Communicatio corporis et sanguinis Ipsius" "Udział w przyjmowaniu Jego Ciała i Krwi", tj. Ciała 1 Krwi Chrystusa albo "Przyjmowanie Jego Ciała

1 Krwi", tj. Ciała i Krwi Chrystusa

"Udział w przyjmowaniu Jego Ciała 1 Krwi", tj. Ciała 1 Krw1 Chrystusa 159 , wspólnie z innymi, w czasach św. Augustyna był praktylia codzienna albo następował w dni ściśle określone, kiedy składano najśriętsza ofiare, np. wobote 1 w niedzielę albo tylko wiedziele, jak rskazuje na to tekst przytoczony niżej.

156 Sermo 17, 5, PL 33, 127: "constituit Deus in Ecclesia tempore miscricordiae praerogandae quotidianam medicinam, ut dicamus, 'Dimitte nobis debita nostra, sicut et nos dimitimus debitoribus nostris, / 1 it $6,12 /$, ut his verbis lota facie ad altare accedamus, et his verbis lota facie corpore Christi et sanguine communicemus".

157 Sermo 131, 1, PL 38, 729: "de corpore ac sanguine suo dedit nobis salubrem refectionem".

158 Confessiones 6, 2, PL 32, 720: "et pro canistro pleno terrenis fructibus ilenum purgatioribus votis pectus ad memorias martyrum afferre didicerat, ut et quod posset daret egentibus et sic communicatio dominici corporis illic celebraretur, cuius passionis imitatione immolati et coronati sunt martyres".

159 Epistola 54, 1, PL 33, 200: "communicatio corporis et sanguinis 1psius". 
26. "Communicare corpori et sanguini Domini"

"Branie udziału w przyjmowaniu Ciała 1 Krwi Pańskiej" albo "Przyjmowanie Ciała i Krwi Parisiej"

o różnej częstotliwości przyjmowania Ciała 1 Krwi Pańskiej tak pisze św. Augustyn: "jedni codziennie przyjmuja Cia$¥ 01$ Krew Pańską, Inn1 przyjmuja w pewno dni; w jednym miejscu nie pomija się żadnego dnia, w któryin by nie składano ofiary, w Innym miejscu składa się Ją tylko w sobotę 1 w niedzielę, gdzle indziej tylko w niedzielę"160.

27. "Participatio corporis ot sanguinis Christi" "Uczestnictwo wiele 1 Krwi Chrystusa" albo "Uczestniczenie w przyjmowaniu Ciała 1 Krwi Chrystusa" luo "Przyjmowanie Ciała 1 Krwi Chrystusa"

"Niech nikt nie mówi, że droga, która'wiedzie do zbawienia, może znajdować sie wasiegu dobrego postępowania 1 kultu jednego Boga wszechmogacego bez uczestnictwa w przyjinowaniu Ciała 1 Krw1 Chrystusa"161. "Papiez Innocenty 162 mów1, że dzieci bez Chrystusowego chrztu 1 bez uczestnictwa w przyjeciu ciała 1 Krwi Chrystusa nie maja zycia wiecznego" ${ }^{163}$.

160 Tamże, 2, PL 33, 200: "alii quotidie communicant corpori et sanguini Domini, alii certis diebus accipiunt; alibi nullus dies praetermittitur, quo non offeratur, alibi sabbato tantum et dominico, alibi tantum dominico". Wyrazy "communicare" $i$ "accipere" oraz "communicatio" oznaczajaz "przyjnowanie" /Ciała i Krwi Paiskiej/, "branie udziału w przyjmowaniu".

161 Epistola 149, 17, PL 33, 637: "Et ne quisquam diceret posse esse salutis via in bona conversatione et unius Dei onnipotentis cultu, sine participatione corporis et sanguinis Christi". Por. Contra Faustum Manichaeum 17, PL 42, $382 /$ nota 111/.

162 Sw. Innocenty I /401-417/.

163 Contra duas epistulas Pelagianorum II 7, PL 44, 576: "Innocentius Papa sine Baptismo Christi, et sine participatione corporis et sanguinis Christi vitam non habere parvulos dicit". Por. De peccatorum meritis et reaissione I 27, PL 14, 124: "sine participatione corporis huius et sanguinis in se habere vitam/sc. non possunt/"; wierzący nie mogiz "micćw sobie źycia bez uczestnictwa w przyjnowania tego Ciala 1 Krwi". 
28. "Participatio corporis et sanguinis Domini" "Uczestnictwo wiele i Krwi Yańskiej" albo "Uczestnictwo w przyjmowaniu Ciała i Krwi Pańskiej" lub "Przyjmowanie Ciała $i$ Irwi Paískiej"

Mówiąc o godnym przyjmowaniu eucharystii św. Augustyn wyJaśnia, że "człowick powinien uznać się za niegodnego do przyjęcia Ciała i Krwi Pańskiej" po popełnieniu grzechu śmiertelnego 164 .

29. "Participatio mensae dominicae"

"Uczestnictwo w przystapieniu do stołu Pańskiego" albo "Uczestnictwo w sakramencie stołu Pańskiego" lub "Uczestnictwo w przyjmowaniu sakramentu stołu Pańskiego" albo "Przyjmowanie sakramentu Stołu Pańskiego"

Biskup Hippony stwierdzając, że "chrześcijanie kartagińscy bardzo słusznie san chrzest nazywaja zbawieniem, a sakrament Ciała Chrystusa życier", posługuje sie przy tym w jednym dość krótkim kontekście swojego wyjaśnienia takimi określentami eucharystii, jak: "sacramentum corporis Christi", "sacramentum mensae dominicae", "corpus et sanguis Domini", "sacramentum". Wóród tych określeń w tym samyin kontekście znajduje się także termin "participatio mensae dominicae": ponadto chrześcijanie kartagińscy "utrzymują, że żaden człowiek, poza chrztem i uczestnictwem w sakramencie Stołu Paŕskiego, nie może dojść nie tylko do królestwa Bożego, lecz także do zbawienia 1 życia wiecznego"165.

30. "Participatio altaris"

"Uczestnictwo w sakramencie ołtarza"

"W samym połączeniu sakramentów, udział w chrzcie, przy uczestnictwie w sakrumencie ołtarza, ma sprawiedliwych, ma tez

164 Sermo 351, 7, PL 39, 1542: "Fostremo ab ipsa mente talis sententia proferatur, ut se indignum homo ludicet participatione corporis et sanguinis Domini". Por. De civitate Dei XXI $25,1, \mathrm{PL} 41,741$ o podkreśleniu łączności sakramentu chrztu z eucharystia: "obmyci przez chrzest Chrystusowy stali sie uczestnikami Ciała i Krwi Chrystusa"-"corporis eius/sc。 Christi/ et sanguinis participes".

165 De peccatorum meritis et remissione I 34, PL 44, 128-129: "Punici Christiani /.../ Unde, nisi ex antiqua, ut oxistimo, et apostolica traditione, qua Ecclesiae Christi insitum 
niesprawiedliwych"166.

31. "Corporis Christi communio"

"Wspólnota Ciała Chrystusa" albo "Zjednoczenie

z Ciałen Chrystusa" lub "Lączność z Ciałem Chrystusa"

Taki termin eucharystyczny znajduje się w augustyńskim tekścio, w którym jest mowa o czyimś "odsunięciu się od łączności z Ciałem Chrystusa"167.

32. "Corporis et sanguinis Christi communio" "Ispólnota Ciała i Krwi Chrystusa" albo "Zjednoczenie

z Ciałem i Krwia Chrystusa" lub "Lącznośc z Ciałem

1 Krwia Chrystusa"

"Te bowiern tradycje przekazana przez 0jcór z'achowuje cały Kościół, aby modlono się za tych, któxzy umarli w łącznośc1 z Ciałem i Krwia Chrystusa, kiedy w czasie samej oflary następuje wspomnienie o nich na waściwym miejscu $i$ aby pamiętano takśe o składaniu za nich tej ofiary"168.

33. "Hunc cibum et potum societatem vult intellegi corporis et membrorum suorum quod est sancta Ecclesia"

"Przez ten Pokarm i Napój według woll Paŕskiej należy rozumieć wspólnote Ciała 1 jego członków, czym jest śvięty Kościót"

Sw. Augustyn tak pisze o tej Tajemnicy: "Chce wiec / $\mathrm{Pan} /$, aby przez ten Pokarm i Napój rozumiano wspólnotę Ciała 1 jego członków, czym jest święty Kościół obecny w przeznaczonych, powołanych, usprawiedliwionych, sławnych świętych 1 jego wier-

tenent, praeter Baptismum et participationem mensae Dominicae non solum ad regnum Dei, sed nec ad salutem et vitam aeternam posse quemquam hominem pervenire?"

166 Serno /dubius/ 364, 2, PL 39, 1640: "in ipsa societate Sacramentorum, communicatio Baptismatis, participatione $\mathrm{Al}$ taris, habet iustos, habet iniust os".

167 Contra duas epistulas pelagianorum IV 26, PL 44, 628:

"a corporis Christi cominunione removetur".

168 Sermo 172, 2, PL 38, 936: "Hoc enim a patribus traditum, universa ooservat Ecclesia, ut pro eis qui in corpor is et sanguinis Christi communione defuncti sunt, cum ad ipsum sacrificium loco suo commemorantur, oretur, ac pro illis quoque id offerri commenoretur". 
nych"169 - Tyıi terminaili określa Biskup Hippony społeczny, uniwersalny 1 eklezjalny wywiar eucharystii. Dzieki jej jednoczacej mocy tworzy się i utrzymuje zjednoczenie w miłości wszystkich braci i sióstr w Chrystusie, czyli w Jego Ciele, tj. w Kościele świętym, czyli w społeczności kościelnej.

34. "Mysteriorum divinorum signacula"

"Znaki oznaczaj ące boskie misteria"

"Do tego ołtarza, który jest postawiony teraz wościele na ziemi, wystawiony przed oczy ziemskie, dláa powtarzania zewnętrznych znaków należących do boskich misteriów, może przystąpic wielu nawet występnych, ponteważ Bóg w obecnym czasie okazuje swoja cierpliwość, aby w przyszłości ujawnić swoją surowość. Przystępuja zaś nie wiedząc, że ciorpliwośč Boża doprowadza ich do pokuty /.../. Natomiast do tamtego ołtarza, dokąd wszed przed nami Jezus jako Poprzednik, dokąd Głowa Kościoła wyprzedziła pozostałe członki mające tam iść, nie bę̧dzie mógł przystąpić żaden spośród tych, o których, jak już wspomniałem, powiedział Apostoł, że 'ci, którzy popełniaja takie występki, nie osiąna królestwa Bożego" "170,

35. "Signum corporis Christi"

"Znak oznaczający Ciało Chrystusa"

Eucharystia jest znakiem oznaczajacym Ciało Chrystusa: "Pan bowiem nie wahał się powiedzieć: 'To jest moje Ciało' / Mt 26, 26/, kiedy dawał znak oznaczający Jego Ciało"171. "Kto

169 In Ioannis Lvangelium 26, 15, PL 35, 1614: "Hunc itaque cibum et potum societatem vult intellegi corporis et membrorum suorum, quod est sancta Ecclesia in praedestinatis et vocatis et lustificatis, et glorificatis sanctis, et fidelibus eius".

170 Serino 351, 7, PL 39, 1543: "Ad hoc altare, quoci nunc in Ecclesia est in terra positum, terrenis oculis expositum, ad mysteriorum divinorum signacula celebranda, multi eticun scelerati possunt accedere /.../. Ad illud autem altare, quo praecursor pro nobis introitt Iesus, quo caput Ecclesiae praecessit, meinbris ceteris sccuturis, nullus oorum accedere poterit, de quibus, ut iam commeiloravi, dixit Apostolus,' Quonian qui talia agunt, regnum Dei non possidebunt".

171 Contra Adimantun Manichaet discipulum 12, 3, PL 42, 144: 
zaś nie rozumie co oznacza znak, a jednak umysłem poznaje istnienie znaku, sam nie znajduje się pod naciskiem stanu niewoli. Lepiej jest nawet doznawać ucisku z powodu nieznanych, lecz pożytecznych znaków, niż wyjaśniając je nieużytecznie, wplątać w sidła błędu kark wyprowadzony z jarzma niewoli"172.

36. "Vita unicuique erit corpus et sanguis Christi" "życ1em dla każdego będzie Ciało i Krew Chrystusa"

Eucharystia jest rzeczywistościa o wymiarze duchowym: "Życiem dla kaźdego będzie Ciało i Krew Chrystusa, pod warunkiem że to, co w sakramencie przyjmuje się w sposób widzialny, w samej rzeczywistości spożywa się duchowo, pije się duchowo"173.

Po dokonaniu przeglądu eucharystycznych terminów u św. Au-. gustyna można stwierdzić, że to nazewnictwo jest: $1^{0}$ imponujące w swoim bogactwie juź w starożytności chrześcijańskiej, czego wymownym dowodem sa augustyńskie pisma; $2^{0}$ aktualne 1 pożyteczne dla określenia tajemnicy eucharystii, której pokojowa $i$ jednocząca moc ciągle jest źy i ma przyszłość w budowaniu Ludu Bożego, lepszego w całości świata; $3^{0}$ praktyczne w zastosowaniu do katechez, kazań, komentarzy biblijnych 1 różnych wyjaśnień; $4^{0}$ głębokie w swojej zawartości treściowej, zwłaszcza w wypowiedziach, które podkreślaja rzeczywistą obecnośs Ciała 1 Krwi Chrystusa w eucharystii, jej duchowy, społeczny, uniwersalny, eklezjalny, trynitarny 1 dynariczny wynlar dla źycia w pełni chrześcijańskiego; $5^{\circ}$ urozmaicone wreszcie także pod wzgledem językowym i stylistycznym.

Ks. Henryk Wójtowicz - Lublin

"Non ellm Dominus dubitavit dicere 'Hoc est corpus meum' Nit 26, 26/, cum signum daret corporis sui".

172 De doctrina christiana III 13, PL 34, 71: "Qui autem non intelligit quid significat signum, et tamen signum esse intelligit, nec 1psc premitur servitute. Melius est autem vel premi incognitis, sed utilibus signis, quam inutiliter ea interpretando, a iugo servitutis eductam cervicem laqueis erroris insererc".

173 Sermo 131, 1, PL 38, 729: "vita unicuique erit corpus et sanguis Christi, si quod in Sacrariento visibiliter sumitur, in ipsa veritate spiritualitor manducetur, spiritualiter bibatur". 


\section{DE VOCIBUS EUCHARISTIAE APUD SANCTUM AUGUSTINUM /Summarium/}

Dissertatiunculae auctor primum de bibliographia Augustiniana pauca commemorat, deinde de sancti Augustini operibus, in quibus nomina eucharistica saepius occurrunt, mentionem fac1t, postea Eucharistiae voces, quas de operibus sancti sugustini $p$. Wunibald roetzer deprompsit atque in opere suo liturgico breviter descripsit, enumerat ac demum propositum suum declarat.

Enumerantur ergo atque in 1 inguam Polonam transferuntur necnon breviter explicantur plurima nomina eucharistica, quae a sancto Augustino usurpantur. Quae omnia dividuntur in partes quattuor, quarum unam complet "isucharistia" cum vocibus sibi proximis, aliam "sacramentum", tertiam saepissime haud dubie occurrens "sacrificium", quartan autem cetera Eucharistiae nomina selecta componunt. Quae saepius locupletiorem quam nostram significationem habent et absque contextu recte intelligi et explicari nullo modo possunt. Ob hanc causam una cum contextu suo proximo afferuntur.

Nomina eucharistica, quae in operibus sancti Augustini haberus, plurima, nobis etian perutilia, ad res magnas exprimendas apta sunt, varietate nos delectant mentemque nostram movent. 